\title{
The Bancroft Collection
}

The Baker Library is particularly happy to announce the gift by Mrs. Hugh Bancroft of Boston, of an exceptionally rich and complete collection on the South Sea Bubble. The collection contains books and pamphlets, with many manuscripts, broadsides, Acts of Parliament, and other fugitive items relating to this strange episode. Except, perhaps, for the material scattered on the shelves of the British Museum, no collection rivals this which was assembled by the late Hugh Bancroft, in its fullness for a history of the South Sea speculation.

Hugh Bancroft became interested many years before his death in this extraordinary speculative mania that swept England in the second decade of the 18 th century. His study of it and his curiosity regarding it were heightened by the interest in this same phenomenon which was shared by Mr. Eaton, my predecessor at the Library, and Professor Gras, our Professor of Business History. In the ten or fifteen years prior to his death, Bancroft bought widely, even lavishly, in an effort to collect everything that pertained to his chosen interest. Undoubtedly it was his intention that ultimately this collection should go to the Library of the Harvard Business School, and while no such specification was carried in his will, Mrs. Bancroft has most generously made the Library a gift of this particularly valuable assembly of historical documents.

The field of this collection is not limited to the South Sea Company, or more exactly to "The Governor and Company of the Merchants of Great Britain trading to the South Seas and other parts of America, and for encouraging the fishing," which was chartered in 1711 , reached the peak of its wild career in 1720 , collapsed with wide-spread repercussions of distress throughout the United Kingdom, and thereafter staggered through a meager existence until its final termination a hundred years or more later. The rise and fall of this company alone would have been subject enough for investigation and collection. Bred in the unhappy condition of British Government finance, aided by corruption and favoritism in high places, and before it was ten years old wrecked by the panic that derived in part from its own efforts to pull down competitors in the speculative orgy, the South Sea Company is well worth the historian's attention. By the meagerness of its actual "trading to the South Seas and other parts of America," or "of encouraging the fishing," and the meagerness of other contributions of the social welfare, it is highly representa- 
tive of the speculative "Bubble," i.e., a joint-stock undertaking the shares of which "were blown up by the air of great words."

The Bancroft Collection in reality extends to all the speculative movement in which the South Sea Company was merely the bellwether, that movement which characterizes the economic and business history of England in the period of the 17 10's. Stimulated by the success of the South Sea Company flotation and carried on by the tide of optimism that the final successful termination of a long series of wars had engendered, there came a multitude of new "companies,"even as we were blessed with new enterprises under somewhat similar circumstances only a decade or so ago! But our experience of the I 920 's pales beside the extravagance of this early English orgy. While many of the "companies" launched in the latter "bubbling"-and especially the earlier ones-were designed for relatively conservative purposes connected with the extension of foreign trade, banking, insurance, or productive industries, the prompt rise in the market value of the shares pertaining thereto and the obvious thirst of the British public for further and more rabid speculation combined to give acceptance to the hair-brained schemes that promoters were not slow in providing. In the end, British "investors" were entrusting their funds to enterprises-some of them surely fraudulent-for reclaiming the bog lands of Ireland, for the sale of medicines ("the Grand Dispensary"), for making butter out of beech-nuts, for insuring marriages against divorce, even for the rearing of bastard children-though doubtless the peak of absurdity was reached by "a Company for carrying on an undertaking of Great Advantage, but no-one to know what it is"! Never before or since have the English people been so hopelessly infected with the virus of the get-rich-quick disease.

Nor was the infection limited to any particular group in the community. A bookdealer from Cornhill and the Dutchess of Marlborough bought and sold in Change Alley, as did the Duke of Portland and the distinguished poet, Alexander Pope. Perhaps without much more than ordinary poetic exaggeration is the description written shortly after the collapse:

How goes the Stock, becomes the gen'ral Cry.

Rather than fail we'll at Nine Hundred Buy. Instead of Scandal, how goes Stock's the Tone, Ev'n Wit and Beauty are quite useless grown:

No Ships unload, no Looms at Work we see, But all are swallow'd by the damn'd South Sea. 
The immediate consequences were such as we would now expect: the great bubble burst. When the South Sea Company stock had reached a price ten times its nominal par and fifteen times the initial cash subscription, and when the shares of other companies had been pushed up in yet greater proportions, the efforts of the former-as already suggested - to prevent or check the creation of competitors in the bidding for "investment funds" initiated a liquidation that soon brought even the bellwether into horrible distress. Parliament sought vainly to allay the storm, the Bank of England was petitioned for aid, but nothing could stop the whirlwind that now had to be reaped.

As in all such disasters (even in our own recent catastrophe), a villain or group of villains was sought. In 1720 the directors of the South Sea Company were singled out for special persecution-even though they surely deserved punishment in high measure for sundry "sins and omissions." One or two found safety in flight, but all that could be reached were deprived of nearly all their property, and some rightly driven from public service.

The secondary effects were yet more serious for the country as a whole than the immediate shock, which of course meant intrinsically (for the most part) only a transfer of wealth from some hands to others. Looking beyond the persons identified by the disillusioned speculators as the generators of its ills, the public spied the mechanism of the joint-stock company. This was deemed responsible only slightly less than the South Sea officers for the general plight. Accordingly the country decided that now the Bubble Act, passed early in 1720 to curb the would-be competitors of the South Sea undertaking, should be rigorously enforced. The spread of joint-stock companies was suspended, and was not resumed really until the I gth century. Thereby English industry was in some degree deprived of capital that otherwise would have been available, and was handicapped by the lack of an institutional form particularly suited to large-scale enterprise.

Moreover, it can also be said that indirectly the whole course of English financial development-especially on the functional sidewas affected by the bubble period of the I 7 Io's and its unhappy conclusion. Even as in France the contemporary and largely similar episode of John Law's "Mississippi Bubble" made the name of "bank" anathema among the French people (and witness in our own day the Credit Lyonnais or the Comptoir d'Escompte), in England the regulations circumscribing the flotation of companies which were evolved in the 1 $9^{\text {th }}$ century appear to reflect-in part at least-memories of the days when "airy projects" floated skyward on every side and 
when subscriptions could be secured for a company the purpose of which there was "no-one to know"!

In the documentation of all this strange episode, the Bancroft Collection is extraordinarily rich. Of course there is a copy of the Parliamentary statute creating the "Company of the Merchants of Great Britain trading to the South Seas and other Parts of America"; and there are various subsequent acts enlarging or amending its rights and powers. There is a precious letter in which William Congreve, the famous dramatist, gave instructions regarding the delivery of $\mathfrak{1}_{25} 8$ stock of the South Sea enterprise; and there are six folio volumes appropriately labeled "Autographs of English, Scotch, and Irish Peers: South Sea Documents," all containing the equivalent of "stock powers" relative to transactions in the shares of this concern. Here are to be found the documents (and signatures) of the Earl of Berkeley and the Duke of Bridgewater, Baron Fairfax and the Earl of Leicester together with scores of other major and minor nobility, all of whom were participants in the national speculation.

A further section of the material is compounded of the many pamphlets of criticism and debate that were unleashed when the "Bubble" was finally pricked and the sanguine speculators found their paper profits melting rapidly away; and of the official documents that came with the trial of the South Sea Directors, and the attempt of the vengeful stockholders to secure some share of the directors' personal fortunes. Of the former, two poetical items are perhaps most interesting. One of them is the "Panegyrical Epistle" written by the famous John Gay who had thought himself "fixed for life" when his South Sea stock had reached a value of $\mathfrak{E}_{20} 0,000$, who despite the warning of friends had refused to sell, and who had finally lost all in the general debâcle. His poem is as caustic as might be imagined. No less so, however, is the effusion entitled "News from Hell: or, A Match for the Directors" which a certain critic named Chamberlen put forth in 1721 , and which contains this tender petition to his poetic Muse:
Assist then, Muse, to Stigmatize this Crew,
And with keen Satire their deep Crimes pursue:
Till the base Villains stung by each sharp Word,
Finish their Lives by Halter or a Sword.

Obviously the Bancroft Collection is a jewel of exceptional quality. The Library and the School may well consider themselves fortunate in receiving such a splendid addition to their assembly of material relating to business history. 